\title{
Study on Social Media in Public Self-regulated Learning
}

\author{
Xiaojing Zhang \\ College of Media \& Communication \\ Wuhan Textile University \\ Wuhan, P.R. China \\ wangyunli002@163.com
}

\begin{abstract}
This document explains and demonstrates the public self-regulated learning using social media. Social media have formed the new fields of public Self-regulated learning currently. The bases of public Self-regulated learning using social media are advanced technologies, policy Support and social demands. This kind of Self-regulated learning can overcome the restriction of space and time of traditional school education, and it is open, convenient and interactive. The greatest challenge of public Self-regulated learning using social media is how to get the accreditation of society and the connection with the traditional education.
\end{abstract}

Keywords—social media, self-regulated learning, knowledge production

\section{INTRODUCTION}

Social media are online media which main features include user creating content and communicating information. Blog, Microblog, Wiki, SNS, Twitter, Facebook, YouTube and MOOC are the major representatives of social media. The applications of social media have been found every aspect of public life.

Many learners establish study groups carry on the online discussion, share a variety of learning resources and learning tools, and utilize the skills and expertise of the staff online and provide support for their further development. The development of social media has constructed a new media environment and formed the new fields of public Self-regulated learning in the education field currently.

\section{The Fundamental Preconditions of Public SELF- REGULATED LEARNING USING SOCIAL MEDIA}

A. The Rapid Development of Information Technology Extends the Platform of Public Self-Regulated Learning

With the rapid development and pervasive application of cloud computing, big data, mobile internet and intelligent terminal, the E-learning and research resources is more and more abundant. These resources present with various media, such as text, photo, audio, video, virtual reality and etc.

Public apply social media to extend the traditional classroom to the Internet. It includes network examination and evaluation, instructional supporting system, instruction management system online, teaching resource management system online, virtual lab and online assessment.

\section{B. The Policy of Educational Information Has Gradually Become an Important Guide to the Sound Development of Education}

The level of informationization is one of the important indicators of international competitiveness, modernization degree, overall national strength and ability of development in economy to weigh a country or region. All countries attach great importance to the planning and development of educational information.

China has introduced a lot of policy of educational information; the National Outline for Medium and Long Term Educational Reform and Development (2010-2020) put forward requirements clearly about strengthening education information construction. Development plan of education informatization decade (2011-2020) promote to accelerate the education informatization strategy.

\section{The Public Should Constantly Learning to Meet the Needs of Society}

With the rapid development of technology and economy, the social demand for talents has profound change. Information quality is the necessary requirement of information society. People increasingly realize the importance of the concepts of life-long learning and self-regulated learning.

Internet provides rich learning resources and convenient means of communication for self-regulated learning. Also, with the rapid development of network and information technology, a variety of learning sites are established, which has set a good foundation for the reform of teaching mode.

Lifelong education is a trendy in the age of information and internet. Public lifelong education has a great significance for the social development. Social media has constructed a new media environment to build a study society. 


\section{THE MAIN CHARACTERISTICS OF PUBLIC SELF- REGULATED LEARNING USING SOCIAL MEDIA}

\section{A. Learner Use Fragmented Time to Learn Self-Regulated in Different Time and Space}

Family, school, work group and society institutions divide public life in space in reality and each individual is not fixed over time. There are many interspaces between the separable space and time. The fragment characteristic of social media has the potential to fill these interspaces. People can take their spare time to learn self-regulated on mobile terminals, such as tablets, i-pad, and smartphones.

The teaching plan and teaching progress are prearranged in the traditional school education. This kind of situation has broken through the restriction of traditional education resources and method so that learners can arrange the study plan and schedule according to their knowledge level and time situation and realize "education individualization" with social media which cannot be accomplished in traditional education[1].

The social media also can realize virtual teaching for teachers and students in indifferent time and space, which is for network teaching and complete corresponding teaching objectives, and achieving to interact between teachers and students.

\section{B. The Study Process Is a Constantly Spread of the Process of Personal Communication}

The social media self-regulated learning is not a learning activity that only happens in a virtual space, it also is a process of personal communication. Learners can interact their knowledge in virtual learning community, and get knowledge through exchange and communication.

The development of social media learning extends education into homes, communities, countryside and any other regions where information technology reaches. This kind of learning is not only a knowledge converging but also a diffusion of social relation, meanwhile, social media have received more concerns.

Education should assist learners to complete their socialization with an open mind. Integrating multimedia textbooks, online research and student presentations with the assistance of new technologies can make learning more interactive and participatory and help learners acquire the competencies needed for today's labor market.

\section{Open Evaluation and Feedback System}

The social media self-regulated learning media has virtually all of its materials online, including quizzes and evaluations. Online quizzes grade accordance with the presupposition procedures and learners can get the score immediately after quiz. Some assignments, papers, drawings evaluate among learners and teachers, and learners at all levels should be encouraged to use this kind of open evaluation system.

Assessment is a dynamic and collaborative process of gathering information in order to form the most complete picture of student achievement and development in a way which will encourage and advance learning [2, 3]. At the same time, learners have spontaneously formed many study groups; can thereby know about their electives and feedback learning experience. Utilizing the interactive study system, the students adjust the studying progress according to their own study situation. The earning exchanges enrich the learning content and raising the convenience of study, and this educational pattern lead the innovation of teaching methods and accelerate the rate of changing the teaching mode.

The future public self-regulated learning should adhere to the student-centered principle, and fully exploit the network technique, cloud computing, clouds computing based education, and large data [4]. Last but not least, an innovative education evaluation system is also indispensable in the reform.

\section{Educators and Learners Need Some Media Literacy}

Currently, emerging information technologies are applied deeply and widely in education. It is driving a new education and learning revolution and brought up new requirements to educators and learners, for example, media literacy. The teaching quality and effect of modern distance education are affected directly with learning consciousness and ability of learners by modern information technology.

There are two aspects of learners to strength media literacy education, i.e., how to understand, distinguish, obtain the information knowledge of media and how to make use of media to perfect individuals. Learners need cultivate capacity to select what they want to learn from large amounts of digital learning resources; to recognize high quality learning resources and support services.

It recommends the best resource of the relevant search engine, and offers the reference information and learning approach for learners to grasp the search skills, the method and the resources of search engines, and optimization retrieval strategy.

\section{The Developing Trend of the Future Public Self- REGULATED LEARNING USING SOCIAL MEDIA}

\section{A. The Learning Places and Mode of Public Self-Regulated Learning Using Social Media Become More Flexible}

Study reform has become a trend for the educational reform in various countries. Meanwhile, it is a building block of learning society and life long studies, which indicates the regression of educational essence. The educational practice full of care must adhere to aim of the all round development of every future citizen, aim at the harmonious progress of education in all regions with varied levels of economic development and emphasize vocational education, lifelong education and self-regulated learning education for public.

The typical trends of this sort of education are as the following: the separation between students and teachers, adopting the specific transmission system and communication media to conduct teaching; the variety of the ways of information transmission; the flexibility of the learning places and modes. Although public self-regulated learning using social media are grounded in distance education, many students 
based online communities. We should think on a long-term view, and consider from global perspective about the future of self-regulated education.

\section{B. Public Self-regulated Learning Using Social Media Is a Kind of Low Cost and Comparatively Fair Education}

Public self-regulated learning using social media is intended to break an educational resources imbalance to allow the less privileged free access to a good education [5]. It should be paid more attention to the scarcity of quality educational resource and make use of school, family and society as an important resource for education.

With the development of education marketization and the increase of personal investment in education, school education is forced into an endless war without boundaries-brand competition. As the cost of a college education goes up, many begin to question whether the expense is worth the reward. For many poorer households, educational investment is not only a highly spent but also a long durational investment. Therefore, parents are very careful for each investment to make sure that their children can reach the sound education. The internet and social media will improve educational conditions and create more opportunities [6]. Utilizing social media learning to resolve the scarce of traditional education resources is a great way which means not only the upgrading to the tools for learning and training but also the reduction of education cost.

Educational equality is a social ideal of education. Public self-regulated learning using social media also guarantees the values of education as a form of public life and empowers students with equal rights. The incapacity of educative power results in different hegemonies and violence in everyday education. There are many inequitable phenomena existing on the equity of education opportunity at present. We should get more financial input into education, pay more attention to the weak mass groups, improve teachers' qualification and promote public self-regulated learning using social media and so on to facilitate the realization of equitable education [7].

\section{Policy Support and Legal Protection Policy Will Be Further Improved}

The public can not access to the Internet without the support of policy. The relevant policies decide the trend and direction of the primary and secondary Internet access. The policy of educational information has gradually become an important guide to lead the sound development of public education in many countries. The state supports, encourages and organizes scientific research in education, and disseminate the results of scientific research in education so as to enhance the quality of education [8-9].

The intellectual property of learning resources is clear. Intellectual property of public resources is the driving force of the development of the knowledge society, and the key is a clear definition of property rights and better resource utilization. The future educational reform is oriented for transforming the functional structure of education according to the requirement of the learning-based society and opening learning resources to all members of the society. Self-regulated learning, life long and diversified learning are inevitable trends.

\section{Learning Resources Need Be Integrated Massively}

Public self-regulated learning using social media means the course in which the learner studies with digital method by using digital learning materials in digital learning environment through the effective configuration of information techniques and learning courses [10-11]. Learning resource integration includes three levels: firstly, infrastructure planning and construction are made up of four levels of structures, including network infrastructure construction, network storing and the expansion of calculating resources, construction of the application platform and system, offering service in door. Secondly, public self-regulated learning using social media, exerting sufficiently the integral advantages of enterprises, universities and research institutes, is the cooperation and integration in respects of function and resources superiority of research, education and manufacture. Thirdly, Learners communicate and cooperate with each other, interact and discuss problems with teachers with social media.

Learners study the use of network resources-rich and fast information retrieval and query tools, a variety of communication tools such as independent access to the knowledge or cooperation, the network can also refer to technology as the main means of self-regulated learning process. Teaching and learning are combined closely so that the study effect is enhanced and the public self-regulated learning using social media teaching quality is improved. Having implemented individuation, self-regulated study will be an independent study with feedback mechanism, it enables the learners to acquire teaching resources what they needed and improve interests of their study.

The accreditation council of self-regulated education should be established, form the system of self-regulated education learning outcomes certification, credit accumulation and transformation and promote continuing education among different types of credit accumulation and transfer work stepby-step [12]. Relevant institutions should integrate validation of adult school and self-regulated learning outcomes in future strategy to meet the challenge from economic crisis, changes in population as well as the severe employment situation.

\section{SUMMARY}

The new knowledge production pattern of social media can be summarized as four steps: the social media assemble learning resource; the learners select content and method online to meet their needs; more learners share learning resource and experience; evaluation and feedback learning effect.

Social media have created an e-learning platform that learners want to customize to their needs. Based on the plat of social media, the design of course contents and resources sharing can make the compiling of educational content more flexible and enable learners to choose the work flow dynamically during the process of learning.

The rapid development of social media open up the way to self-regulated learning, which provides a better environment for the learners to study and test themselves at any time and in any places, helps teachers to get the feedbacks from the learners in time. 
It may encounter many difficulties during public selfregulated learning using social media, especially how to gain the acknowledgement by society and dock with the tradition education. Some schools, educators, research institutes are very reluctant to access to quality education resources, and they concern about the development of distinctive disciplines, lowering academic standards, celebrity teachers negatively impact on enthusiasm of other educators. Meanwhile, it prevents the forward of public self-regulated learning using social media how to calculate the amount of workload, compensation and recognition of achievements.

\section{ACKNOWLEDGMENT}

This research was financially supported by the Foundation of Wuhan Textile University (Grant NO. 153055) and Educational Research Foundation of Wuhan Textile University (Grant NO. 201605024).

\section{REFERENCES}

[1] B.J. Zimmerman, "Self-regulated learning and academic achievement," Educational Psychologist, vol. 25, 1998.

[2] S.J. Mak, What are the main differences among those MOOCs?[EB/OL]. [2012-04-.01].http://suifaijohnmak.wordpress.com/2012/04/01/changellcckl2-what-are-the-main-differences-among-those-moocs/

[3] Downes. E-Learning 2.0 [EB/OL]. http://elearnmag.acm.org/featured. cfni?aid=l 104968, 2012-09-23.

[4] A.M. Kaplan, H. Michael, "Users of the World, Unite! The Challenges and Opportunities of Social Media,” Business Horizons, vol. 53. 2010, pp. 61.

[5] B.M. Sharan, The New Update on Adult Learning Theory: Informal and Incidental Learning, San Francisco: Jossey-Boss, 2001.

[6] H. Theo, "Micro learning: A New Pedagogical Challenge (Introductory Note)", Micro learning Conference. 2006, pp. 7-12.

[7] D.P. Ronald, The relationship between self-directed informal learning and the career development process of technology users, Walden University, 2007.

[8] Harvard Business Review Analytical Services, The New Conversation: Taking Social Media from Talk to Action, 2010.

[9] B.D. Paul, “Models for e-government," Transforming Government: People, Process and Policy, vol. 1, 2007, pp. 7-28.

[10] P.R. Newswire. New California Legislation to Provide MOOC Courses Full Academic Credit [EB/OL]. [2013-04-25].
[ http://www.prnewswire.com/news-releases-test/newcalifornialegislation-to-provide-mooc-courses-full-academic-credit197865351.html.

[11] Spannerworks, what is social media?, http://www.docin.com/p18534898.html,2007,1,22[OL].

[12] A.J. Flanagin and M.J. Metzger, "Perceptions of Internet information credibility,” Journalism \& Mass Communication Quarterly, vol. 77, 2000, pp. 515-540. 